\title{
Patrick Loobuyck, De seculiere samenleving. Over religie, atheïsme en democratie
}

\author{
Stefan Rummens
}

Patrick Loobuyck, De seculiere samenleving. Over religie, atheïsme en democratie (Antwerpen: Houtekiet, 2013), 253 p.

In het Vlaamse publieke debat is moraalfilosoof Patrick Loobuyck van de Universiteit Antwerpen de voorbije jaren een vertrouwd gezicht geworden. In discussies over de plaats van religie in onze moderne democratische rechtsstaat - discussies zoals die over de hoofddoek op school, over het boerkaverbod, over godsdienstonderwijs, ... - treedt hij regelmatig naar voren met een duidelijk maar doorgaans ook genuanceerd standpunt. In zijn recente boek over De seculiere samenleving, dat in eerste instantie bedoeld is voor een ruimer geinteresseerd publiek van nietexperten, herhaalt en verduidelijkt hij zijn opinies door ze te kaderen binnen een meer omvattende historische, sociologische en filosofische analyse van de moderne seculiere samenleving en de haar kenmerkende verhoudingen tussen religie, atheïsme en democratie.

In het debat over multiculturalisme en religie is dit boek een verademing omdat het boek compleet verstoken blijft van de antagoniserende retoriek en de overtrokken aandacht voor symboliek die de discussies al te vaak kenmerkt. De rustige en zakelijke stijl die de auteur hanteert in zijn media-interventies, wordt ook hier doorgetrokken. Die stijl ligt daarbij overigens in lijn met de inhoudelijke positionering. Loobuyck legt omstandig uit dat de moderne democratische rechtsstaat het best begrepen wordt in termen van een 'politiek liberalisme' dat de neutraliteit van de staat vooropstelt en daarbij 'gelijke afstand' houdt tot zowel religieuze als atheïstische posities. Hoewel de auteur zich uitdrukkelijk bekent tot het atheïsme, impliceert het seculiere (d.w.z. neutrale en dus areligieuze) karakter van de democratische rechtsstaat volgens hem nu eenmaal dat niet-fundamentalistische vormen van religie een volwaardige en blijvende plaats binnen de samenleving moeten krijgen. Het militante atheïsme (denk aan auteurs als Richard Dawkins of Christopher Hitchens) is een legitieme positie die ook ruimte moet krijgen, maar die - zo stelt Loobuyck bewust provocerend - tegelijkertijd ook een hobby moet blijven: het atheïsme kan zelf als levensbeschouwing nooit bepalend zijn voor wat de overheid moet doen. Loobuycks 'gematigde' positie moet daarbij echter zeker niet verkeerd begrepen worden. De neutrale overheid is uiteraard niet strikt neutraal maar wel degelijk gebaseerd op de fundamentele en substantiële waarden van vrijheid en gelijkheid. Die waarden kunnen en moeten in een democratische rechtsstaat dan ook steeds op een consequente en desnoods militante wijze verdedigd en afgedwongen worden. 'De vijand van de seculiere staat is niet de religie, maar de (fundamentalistische) religie en andere ideologieën voor 
zover ze de grondrechten en de uitgangspunten van de liberale democratie niet aanvaarden' (p. 242).

Het boek bestaat uit drie delen. Het eerste deel behandelt het fenomeen van de secularisering. Het eerste hoofdstuk bevat een eerder sociologische analyse, ruim gelardeerd met cijfermateriaal, over de aard en de omvang van de ontkerkelijking en de ontzuiling in Vlaanderen alsook over de in de laatste decennia toegenomen religieuze diversiteit (en vooral de grotere aanwezigheid van de islam). Met betrekking tot de vaak gestelde vraag of religie ook in de westerse wereld aan een 'terugkeer' bezig is, neemt Loobuyck een duidelijk standpunt in: samen met godsdienstsocioloog Steven Bruce argumenteert hij dat de secularisering een onomkeerbaar proces is en dat de toegenomen aandacht voor religie in het publiek debat net bevestigt dat de religie haar vroegere vanzelfsprekendheid meer en meer verliest. Het tweede hoofdstuk is veel historisch-filosofischer en bespreekt de secularisering als een eeuwenoud en doorlopend proces, waarbij de religie haar omvattende greep op de samenleving geleidelijk aan heeft verloren en waarbij de politiek en de moraal in een sociologisch proces van differentiëring uiteindelijk autonome maatschappelijke domeinen geworden zijn, die zich voor hun legitimering van de religie hebben ontvoogd.

In het tweede deel bespreekt Loobuyck het politiek liberalisme als een gedachtegoed dat ten grondslag ligt aan onze moderne, seculiere rechtsstaat en dat een gelijke afstand bewaart tot zowel religie als atheïsme. In het derde hoofdstuk krijgen we opnieuw een historisch-filosofische analyse die laat zien hoe de idee van (religieuze) tolerantie, die ontstaat aan het begin van de moderne tijd, doorheen de eeuwen uitgroeit tot een volwaardige notie van godsdienstvrijheid waarin andersdenkenden niet meer halfslachtig 'getolereerd' worden, maar waarin iedereen in vrijheid zijn eigen overtuigingen kan belijden en beleven. Het vierde hoofdstuk behandelt de neutraliteit van de staat en gaat uitdrukkelijk in op een heel aantal actuele kwesties zoals het dragen van hoofddoeken, het boerkaverbod, de grenzen van de vrijheid van meningsuiting en de strijd tegen radicalisme. Hier laat Loobuyck op interessante en in mijn ogen overtuigende wijze zien dat de doctrine van het politiek liberalisme op sommige vragen wél een duidelijk antwoord kan bieden (een verbod op godslastering is onwenselijk, geen kruisbeelden in Italiaanse publieke scholen, een recht om te beledigen ...) en op andere vragen dan weer veel ruimte laat voor een 'margin of appreciation' waarbij meerdere beleidsopties aanvaardbaar kunnen zijn en meer lokale pragmatische en contextuele argumenten een rol kunnen spelen (hoofddoekenverbod op school, weigerambtenaren, financiële ondersteuning van religies vanuit de overheid, ...).

In het derde en laatste deel van het boek bekijkt Loobuyck de seculiere staat vanuit het perspectief van zowel de religie als het militante atheïsme. Wat betreft de religie sluit hij zich hier aan bij de eisen die Jürgen Habermas oplegt aan moderne, reflexieve religies en die noodzakelijk zijn om religie te verzoenen met de democratische rechtsstaat. In hoofdstuk vijf bespreekt hij de vereiste dat religies het redelijk pluralisme van de moderne samenleving moeten erkennen en daarbij moeten aanvaarden dat de politieke orde in de democratische rechtsstaat geba- 
seerd is op een profane moraal. Meer concreet gaat Loobuyck daarbij in op de vraag in welke mate de meest prominente religies in onze samenleving (katholicisme, protestantisme en islam) al dan niet al aan die voorwaarden voldoen. In hoofdstuk zes komt de verhouding tussen geloof en wetenschap ter sprake. De vereiste voor de moderne religie om de autoriteit van de wetenschap ten volle te erkennen is voor Loobuyck essentieel maar volgens hem ook de moeilijkste vereiste om aan te voldoen. In dit hoofdstuk laat de auteur zich van zijn meest atheïstische kant zien en worden ernstige vragen gesteld bij de mogelijkheid om een religieus geloof werkelijk te verzoenen met de moderne wetenschappelijke inzichten. Dat deze twijfel tegelijkertijd ook de mogelijkheid van het bestaan van 'redelijke religies' - en daarmee een van de basisaannames van het politieke liberalisme - in vraag lijkt de stellen, schijnt Loobuyck niet ten volle te beseffen en wordt door de auteur ook niet verder gethematiseerd. Hoofdstuk zeven, ten slotte, neemt het perspectief in van het militante atheïsme en argumenteert dat het vanuit atheïstische kant onredelijk zou zijn om religie zonder meer af te schilderen als een achterlijk en schadelijk fenomeen. De morele en politieke verdiensten van de religie zijn ambigu en vanuit het standpunt van de seculiere staat moet religie een blijvende erkenning krijgen binnen de moderne samenleving.

Aangezien ik dit boek erg evenwichtig en overtuigend vind, heb ik slechts enkele kleinere punten van kritiek. Mijn voornaamste bedenking geldt de wat schoolse en erg historisch-filosofische hoofdstukken twee en drie over secularisering en tolerantie. Hoewel die hoofdstukken op zich instructief en goed geschreven zijn, is hun relevantie voor het hedendaagse debat eerder indirect. Een alternatieve optie zou geweest zijn om ze te vervangen door (of aan te vullen met) een meer uitgebreide bespreking van de hedendaagse filosofen die aan de basis liggen van Loobuycks eigen positie. Hoewel met name John Rawls en Jürgen Habermas voortdurend op de achtergrond aanwezig zijn, worden hun theorieën over politiek liberalisme en de democratische rechtsstaat nergens op een meer systematische wijze uiteengezet. Een dergelijke uiteenzetting had het boek zonder veel extra drempels of inspanning toch wat meer filosofische diepgang kunnen geven en had de lezer een scherper beeld kunnen geven van Loobuycks eigen positie binnen het lopende academische debat. Een andere, minder zwaar wegende bedenking betreft het ontbreken van voetnoten in het boek. Hoewel dat een bewuste keuze is van de auteur, impliceert het wel dat sommige citaten zonder bronvermelding gegeven worden en maakt het het voor de geïnteresseerde lezer die zich verder zou willen verdiepen in een of ander argument of debat, moeilijker om zijn weg in de verdere literatuur te vinden. Dit manco wordt deels gecompenseerd door de literatuurlijst op het einde van het boek, maar toch had het boek gemakkelijk en opnieuw zonder veel extra drempels een wat meer wetenschappelijk karakter kunnen krijgen.

Voor de potentiële Nederlandse lezer moet gezegd dat dit boek zich in eerste instantie richt op een Vlaams publiek. De meeste voorbeelden en zeker ook de sociologische analyse in het eerste hoofdstuk betreffen de Vlaamse situatie. Toch is het boek volgens mij ook voor de Nederlandse lezer nog steeds erg aantrek- 
kelijk. Ook Nederlandse (en andere Europese of Amerikaanse) situaties en gebeurtenissen komen immers regelmatig ter sprake. Meer ten gronde geldt dat de filosofische analyse van de seculiere samenleving en de implicaties daarvan voor de plaats van religie en atheïsme in de democratische rechtsstaat die hier geboden wordt, vrijwel steeds zonder meer zowel op de Belgische als op de Nederlandse context van toepassing zijn.

Hoewel het boek wel degelijk regelmatig naar meer en minder bekende rechtspraak verwijst ter illustratie van een aantal kwesties, is het boek zeker geen rechtsfilosofisch maar wel in eerste instantie een politiek-filosofisch boek. Toch denk ik dat het - misschien juist daarom - ook voor de geïnteresseerde jurist of rechtsfilosoof een erg interessant werk kan zijn. Het plaatst de lopende juridische en rechtsfilosofische discussies over neutraliteit en de plaats van religie immers op interessante wijze in een ruimer historisch, sociologisch en filosofisch kader. Dat de auteur daarbij steeds nuchter en genuanceerd blijft argumenteren zonder daarbij de eigen stellingname te schuwen, maakt dit boek tot een belangrijke aanwinst voor het publieke debat. 